Маја М. Димитријевић Универзитет у Крагујевцу Факултет педагошких наука у Јагодини

Катедра за дидактичко-методичке науке
УДК: 821.163.41-32.09 Андрић И. https://doi.org/10.18485/uzdanica.2020.17.2.14

Оригинални научни рад

Примљен: 31. август 2020. Прихваћен: 11. децембар 2020.

\title{
ГОВОР ПРОСТОРА У АНДРИЋЕВОЈ ПРИПОВЕЦИ „ЗЛОСТАВЉАЬЕ”
}

$A \bar{u} c \bar{u} p a \kappa \bar{u}:$ У раду се разматра на који начин појединости из уметничког простора усмеравају читалачку рецепцију ликова и догађаја у Андрићевој приповеци „Злостављање” (1946). На „језику просторних односа” тумачи се етичко-психолошка димензија породичних релација и проблематика разарања брачне институције у карактеристичном социокултурном контексту. У центру истраживачке пажње нашла се комплексна унутрашња дескрипција ликова, где битну улогу имају просторне супротности на вертикалној оси (горе-доле), а посебно опозиције у хоризонталној равни (унутра-споља). У уметничком склопу Андрићеве приповетке кућа постаје метафора за помирене крајности - жељено и остварено, недозвољено и допуштено. С друге стране, кућни простор има и топофобијску конотацију и у њему се генерише идеја о бекству или смрти, што је за главну јунакињу једнако ослобађању и коначном спасењу. Закључак је да структура простора представља једно од главних изражајних средстава и непосредно утиче на карактеризацију и трансформацију/деформацију ликова у приповеци „Злостављање”.

Кључне речи: Иво Андрић, „Злостављање”, књижевни лик, простор, просторни односи, топофобија.

У појединим приповеткама објављеним после Другог светског рата Иво Андрић се бавио и рефлексом друштвено-историјских кретања на етику и психолошке односе у грађанској породици, деформацијом и разарањем брачне институције „у којој се обавезно један од чланова преображава у психичку и моралну наказу, а други у жртву” (Вучковић 1974: 383). У приповеци „Злостављање” (1946) писац третира проблематику брака у специфичном социокултурном контексту, али исто тако даје и комплексну унутрашњу дескрипцију ликова. Ту је, према речима С. Леовца (1979: 81), „традиционално реалистичко приповедање обогаћено слојевима ироничног и саркастичног говора", а М. Пантић (2009: 179) сматра да је ова прича један од врхунаца Андрићевог реалистичног, психолошки одређеног приповедања. Овом приликом сагледаваћемо и тумачити појединости из равни уметничког простора 
поменуте Андрићеве приповетке. Покушаћемо да утврдимо на који начин слој упросторених детаља у „Злостављању” „програмира, усмерава наш начин читања" (Петковић 2010: 43).

О уметничком простору у књижевном делу Ј. Лотман (1993: 271) говори као о континууму у којем се размештају личности и одиграва радња. Он се критички осврће на наивну перцепцију која стално подстиче читаоца на поистовећивање уметничког и физичког простора. Будући да читалац има потребу да јунака и догађање у неком наративу смести у известан простор који креира у својој читалачкој имагинацији дајући му одговарајуће материјалне карактеристике - и Лотман ће се ипак сложити да „простор обавезно задржава, у својству првог плана метафоре, представу о својој физичкој природи”. Иво Андрић је једном приликом истакао да га је „већ на почетку књижевног рада заокупљала мисао: како приказати човека у времену које се креће као жив организам, и у простору без оне статичности коју рам намеће слици" (Андрић 1994: 296-297). Језик просторних односа једно је од средстава уметничког моделовања, другим речима, једна од компонената општег језика којим говори уметничко дело (в. Лотман 1993: 272). ${ }^{1}$ Спацијалне релације сугеришу односе међу ликовима и успостављају одређена значења и смисао. ${ }^{2}$ Опросторавање ствара специфичну психолошку атмосферу, док опречно постављени елементи у уметничком простору и те како могу бити релевантни за семантизирање будући да „уметнички простор представља модел света датог аутора изражен језиком његових просторних представа” (Лотман 1993: 265). У Андрићевој приповеци „Злостављање” битну моделативну улогу имају супротности на вертикалној оси (горе-доле), а посебно опозиције у оквиру хоризонталне равни (унутра-споља).

Граничне линије текста - његов почетак, крај и наслов - одредиле су и правац кретања у нашем тумачењу. Већ је у наслову делимично усмерена читаочева путања кроз текст приче. Претпоставимо да је прва помисао изазвана насловном лексемом - идеја о физичком малтретирању. Почетно очекивање биће донекле преварено јер је овде реч о духовном злостављању, вербалном и моралном малтретирању између четири зида. Злостављање се етимолошки објашњава као зло, рђаво, нечовечно поступање према некоме, мучење (РС 2007: 473). Подразумева злостављача (мучитеља) и жртву. Та двострукост наговештава паралелизам у композицији. Наиме, читава наративна схема обликована је кроз опозитне односе: два антиподна лика - Андрија Зереко-

${ }^{1} \mathrm{У}$ једној студији која се бави улогом и значењем простора и времена у уметничким делима истакнуто је да се „проблем простора налази [се] у самом средишту погледа на свет свих система мишљења који се појављују; он предодређује структуру читавог система [...] поимање света јесте поимање простора” (Флоренски 2013: 252).

${ }^{2}$ Или, како би Ј. Лотман (1993: 279) рекао: „Сваком простору одговара особен тип односа личности које у њему функционишу.” 
вић и његова жена Аница, причање и слушање, дневна и ноћна егзистенција, отворен јавни живот и затворен, приватни животни простор. „Приповетка приказује мейаморфозе овог трговца [Андрије Зерековића] од лика какав је пред чаршијским светом до лика какав уистину јесте и какав би хтео да буде" (Леовац 1979: 82), „процес метаморфозе свести од свог нормалног склопа до чудовишног изобличења" (Вучковић 1974: 384).

Задржимо се, најпре, сасвим кратко, на презимену главног мушког лика. „Човек у први мах не може да схвати шта се све крије у презименима... Ту можете видети порекло, лозу, занимање људи. Цела структура развоја, обичај, наслеђе - све се то може наслутити у презимену" - каже писац (Андрић 1994: 265-266). Зерек је део старог Београда на дорћолској падини, трговачки кварт, „чиме писац наглашава озбиљност и грађанску солидност лика указујући и на стабилност позиције на социјалној лествици. Што је варка, наравно”, рећи ће М. Пантић (2009: 177) помињући „Злостављање” као једну од антологијских Андрићевих приповедака из београдског круга, посвећених малим људима. Ако се упустимо у нешто слободнију интерпретацију корена презимена јунака, доћи ћемо до речи зер, што је врста јастреба који се устремљује на своју жртву, птица грабљивица, а тиме би, донекле, могло да започне „одгонетање метафоричног смисла који текст носи” (Петковић 2010: 43).

Почетак приповетке обликован је као директно, in medias res caопштење без експозиције. Најпре је дат расплет једне животне ситуације, окончање једног брака као повод за нарацију која ће се реализовати према ретроспективном моделу „из објективне, свезнајуће приповедачке перспективе” (Пантић 2009: 177). Прича је, заправо, намера да се образложе узрочно-последичне везе и обелодани повод онога што се догодило. На оквирима приповедне целине појављује се аутор који даје најобухватнији опис. Он овде коментарише ликове, повезује књижевни свет са ванкњижевним елементима, тендира ка приближавању сопственог и читаочевог знања и искуства тако што се читаоцу непосредно обраћа: као шито смо већ рекли..., йознай вам је

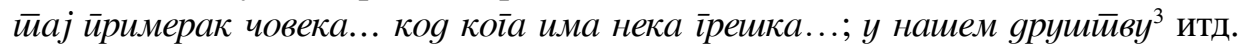
Истовремено се појављују коментари са иронично-подсмешљивим валерима, формирајући метараван испуњену скривеним ауторским сигналима. Повремено се он повлачи из приповедања, не видимо његове личне особине, а приказивачка тачка гледишта се везује за свест лика - „у објективном приповедању у 3. лицу, пушта да расте удео остављен перспективи личности и оптици њене мисли где се догађа све оно суштинско” (Русе 1993: 182).

${ }^{3}$ Сви наводи из приповетке „Злостављање” у овом раду биће означени курзивом, према издању Иво Андрић, Знакови - приповетке, Сабрана дела - књига осма, Београд, 1967, 105-133. 
Прва реченица, „дакле она од које и започиње читање” (Петковић 2010: 43) и разумевање „Злостављања” гласи: Сви су се изјаснили йройив Анице. Овим се исказом у причу уводи опште мишљење и преноси атмосфера налик на ону у судници, кад порота доноси оптужујућу пресуду јер је Аница Марковић својом вољом и без неког очигледног мотива напустила мужа, трговца Андрију Зерековића. „Нико, осим приповедача и ње, не зна зашто је изабрала такав живот напустивши привидно узоран грађански брак” (Пантић 2009: 177). Помиње се да је отац није примио у кућу зато што је беснуља-йобеїуља која йражи хлеба наg йойачу и она остаје усамљена на супротној страни, изолована и одбачена. Пословички народни изрази којима је Аничин отац заклонио своју сурову одлуку пропраћени су ауторским запажањем да се йословицама коg нас убијају живи љуяи на најбржи и најнейравеgнији начин. Овим се призива контекст културних норми средине којој припадају ликови, њихово окружење и сам аутор. Структура целокупног приповедног простора функционише као једно од главних изражајних средстава и притом се дели на два неједнака дела. ${ }^{4}$ Први од њих - готово сасвим недетаљизован, јесте

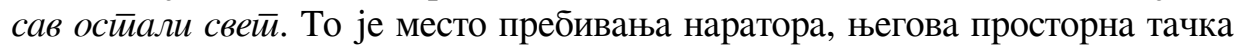
гледања (в. Лотман 1993: 281), па се рефлекс одређених правила или неписаних а густо премрежених захтева прелама у овим нараторским пасажима. Ту ће он „своју индивидуалну говорну перспективу заменити општијом”, с тим што не „говори у име неког неодређеног колектива” (Микић 2005: 108), него са извесне дистанце одмерава и критички вага последице утицаја и притиска таквог окружења на појединца. Приповедачу је, чини се, потребно да потцрта нека начела овакве колективне егзистенције. То потврђује и уметнуто резимирање о резонима наслоњеним на безусловно прихватање гнома. Оне су одраз и израз наталоженог, вековног искуства, сведоче о правилности дешавања и укидају могућност за супротстављање. Уопштавање се сучељава са личним - индивидуа нема право да се издвоји и понаша другачије јер ће, у супротном, морати да страда. Саопштавање ставова локалног јавног мњења наставља се на следећи начин: И заистй, нико није моїао gа разуме зашйо је Аница, жена Анярије Зерековића, найусииила јеgног̆ gана кућу и мужа. Одрична заменица допуњује и потврђује онај једнодушан став с почетка. Не само комшилук и йознаници неїо, са малим изузецима, и њена йородица делили су мишљење које се сударило са стигматизованим појединцем. Јунакиња је

${ }^{4}$ „Лотман је такође запажао да је свет представљен у књижевности често подељен у простору на два супротстављена дела (на пример, свет живих-мртвих, наших-туђих, богатихсиромашних, фантастичних-реалних и сл.), а прекорачење границе између ових светова игра веома важну и битну улогу за конструкцију фабуле - представља, заправо, рушење устаљеног поретка и, захваљујући томе, постаје једна од надређених тематских категорија књижевности" (Бужињска, Марковски 2009: 271). 
приказана „онаква каква се она појављује пред страним погледом вањског сведока и оцењивача" (Русе 1993: 17).

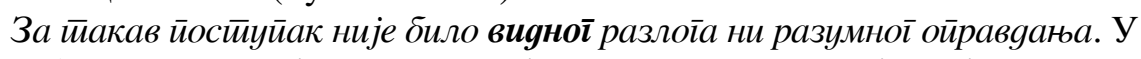
овом тврђењу препознајемо подстицај за нови тип опозиције, која подразумева следеће антитетички постављене елементе:

- оно што је приметно на први поглед, видљиво, оспољено, доступно туђем оку;

- оно што се не види, затворено у ужи простор (у породичне оквире), скривено од света.

Сегменти приче на које смо указали потенцирају се понављањем: иривияно удобан и задовољан живот; наоко срећно удомљена Аница, једино дању истински мирна, ноћу узалудно тражи мало мира и сна; наоко углађен, прибран и поштовања достојан четкар Андрија Зерековић, по дану приморан да суспрегне свој немир и прикаже се онаквим каква су очекивања грађанске културе којој припада, а ноћу ћудљиви егоцентрик и вербални тиранин. ${ }^{5}$ Примећујемо да се паралелно са истакнутим опонирањем успоставља још једна двострукост у животима јунака, а у вези са смењивањем дана и ноћи: „дан и ноћ постају средство да се покаже нека врста располућености, нека врста поделе и јунаковог живота и његовог унутарњег света" (Микић 2005: 109).

Приповедач зна шта је са Аницом било после - у његовом процењивачки ангажованом коментару она је названа сиройом самицом која gанас ради као продавачица. Истакнуто је време из ког се приповеда као најава за ретроспекцију. Уколико се придржавамо уобичајеног хронолошко-логичког следа, требало би да се одељак о садашњем Аничином животу, сличан епилогу, нађе на крају приповетке. Уметањем пасуса са епилошким карактером на почетак приче сигнализирано је да ништа важно више не може да се догоди - инверзна позиција завршног објашњења потврђује да се јунакињин живот претворио у смирено трајање. Али то што ради као продавачица у једном великом магазину, што је омршавела, убледела, што станује у једној собици - оставља места питањима о греху и казни, о привиду и истини. Смењивањем проспективног и ретроспективног приповедања мозаички се склапају компоненте приче. Посебна организација времена, кретање напред-назад, један је од модуса којим се одгонета смисао и долази до поенте. Такав композициони поступак намеће и нешто „што бисмо могли да назовемо двосмерно читање,

${ }^{5}$ „Зато је и техника којом се та подвојеност приказује двострука. Некад се из спољашње перспективе приказује како лик дјелује, при чему више или мање може бити наглашено како реагују они који посматрају, или трпе то дјеловање, а некад је у првом плану унутрашњост лика, и тада се приказују психолошки процеси" (Радоњић 2016: 737-738). 
а у целини нас прецизно усмерава ка семантичкој жижи, ка самом средишту наративног описивања" (Петковић 2010: 46).

У функцији образлагања општег мишљења дат је портрет Андрије Зерековића, сажето, издвајањем само битних детаља. Каже се да је имао фабрику четака, а онда следи упозорење да је то искључиво визура лика, па ће приповедач трансформисати његове речи сводећи их на реалну меру („фбабрика" је можgа мало сувише круйна реч, то је, у ствари, лепо уређена радионица са дванаестак радника), што доводи у сумњу њихов значај и информативну тачност. Овакав тип интервенције, којом се, наводно, афирмише објективно приказивање, заправо хотимично смера ка негативној карактеризацији. Она ће убрзо бити изложена у крајње експлицитној форми, а односиће се, за почетак, само на физичке одлике лика. Газда Андрија је сељачко дете, штедљив, радан, пажљив, сладак у говору, послован, угледан, али никада наочит и леп. Све је код њега било савршено, осим спољашњег изгледа. Почетно описивање са одобравањем и наклоњеношћу у ствари је подлога за појачано контрастирање и оштар заокрет ка неочекиваном закључку: био је савршен $\bar{u} и \bar{u}$ ружно̄ човека. Духовит обрт и поигравање речима функционише као унижавање, а портрет се приближава карикатури. Понављањем сличних дескриптивних замаха гротеска постаје иманентан састојак у портрету овог јунака. Аница је пак била сирота, ћутљива, крупна, стасита лепотица која се стидела да ту своју лепоту покаже и ничим се није истицала.

У неколико наврата објашњавање започиње идентичним синтагмама:

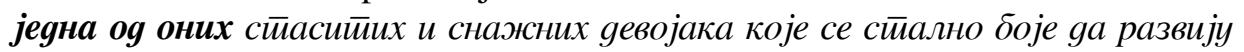

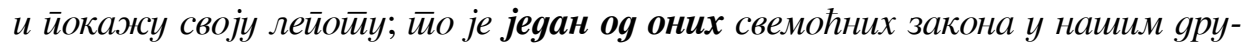
ийвеним оgносима; йо је јеgна оg оних уgаја о којима се ирича не само у

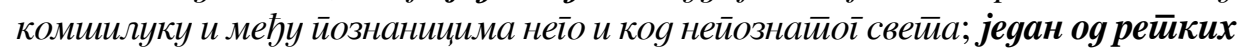

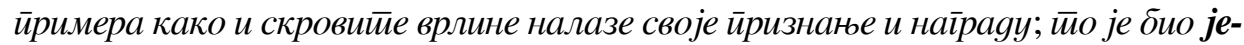

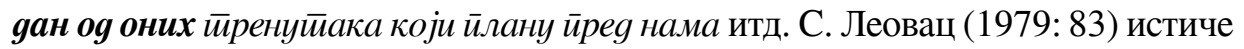
да се код Иве Андрића ретко проналази овакав начин паралелизма и критикује слична претеривања и понављања. Требало би, међутим, узети у обзир и чињеницу да је гомилање таквих конструкција свакако у тесној смисаоној вези са исходом исприповеданог, али и да ауторска инстанца себе жели да представи као доброг опсерватора, чак као хистора који непогрешиво препознаје суштину, упоређује и сврстава, а кроз чије причање промиче призвук општеважећег мишљења, повремено засенченог иронијским наносом. Све о чему он приповеда већ је познато, виђено, устаљено, клишетирано. Ликови су обични, просечни људи, не нарочито привлачне појаве и код читаоца могу да наиђу на равнодушност, можда и на антипатију. Принцип паралелизма по супротности (он богат и самозадовољан : она сирота и повучена) спроводи се у структурирању приповетке, као што ћемо још видети, на неколико ни- 
воа $^{6}$ и „усмерава наш питалачки поглед ка средишњем догађају” (Петковић 2010: 46) интензивирајући и запитаност и знатижељу: шта ће се толико важно, односно на који начин ће се нешто необично догодити оваквим обичним ликовима. Врло је фреквентан тип напоредног односа међу реченицама, што указује на антиномичност и изразиту подвојеност која ће довести до размицања и коначног раздвајања судбинских путева јунака.

У социјалне оквире умећу се и породичне релације и обичајне норме:

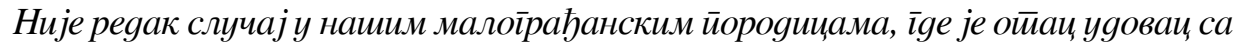

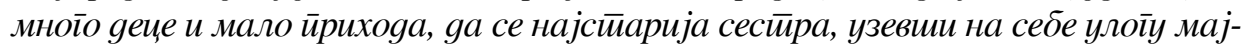

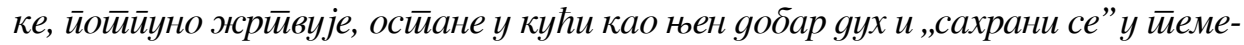
ље йороgице. С једне стране се приказује психолошки профил Аничиног оца (човек мрїоgан и ирреке нарави), а посебно место у приповеци припада кући, која је оличење газда Андријине успешне трговачке каријере. Специфична врста везе успоставља се и између Анице и куће: она се пролепшала па је и кућу преобразила својим присуством ${ }^{7}$. Жена код Иве Андрића инспирише, покреће и на добро и на зло, чини огроман напор да очува нормалан, складан породични живот. За Андрију Зерековића женидба је значила рај йоййуно

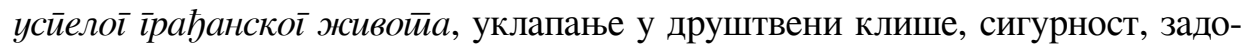
вољство, срећу. Кућа постаје метафора за помирене крајности - жељено и остварено, недозвољено и допуштено: Cag је моїао о йразнику gа йрошейа са белоликом, ћуйљивом, добро одевеном, својом женом. Андрија Зерековић сопствену жену све више посматра и доживљава као лични посед, а мислећи о њој, први пут почиње да се удубљује и у мисао о себи. Постаје склон самопосматрању и самоанализи. Од тог тренутка, све што се тицало јавне сфере и спољашњег простора, што је било рационално, видљиво и дешавало

${ }^{6}$ Р. Вучковић (1974: 389) запажа да су у „Злостављању” поједине приповедачке ситуације оштрије моделоване тако што је на једној страни карикиран лик Андрије Зерековића, а на другој лирски дата патетика трпње која се везује за Аницу; човек-„насилник” чија је физичка снага незнатна, али чији су живот, грађа тела и душе механизовани до крајњих граница суочен је са женом, која је имала све особине богатог бића. Уз то, „сугестивност приповедања остварује се и доследним грађењем контраста. Спољна представа о јунацима у нескладу је са њиховим стварним, унутрашњим стањем” (Пантић 1999: 255).

${ }^{7}$ У роману Нечисти а крв Боре Станковића главна јунакиња Софка приморана је, због удаје, на драматичну промену животног простора. Она долази у разграђену, сеоску кућу, и отуда има потребу да све ушушка, утопли, умекша, да углове испуни јастучићима како би унутрашњост бар донекле подсећала на њен хаџијски дом у којем се осећала заштићено (в. Петковић 1988: 110-111). Иако доследно упоређивање ове две приповедне ситуације није сасвим изводљиво, приметно је да Аница такође оплемењује кућу у коју се удала својом лепотом и чулношћу: У новој кући Аница се оgмах у йочейку ослобоgила и йролейиала. Њена лейойа

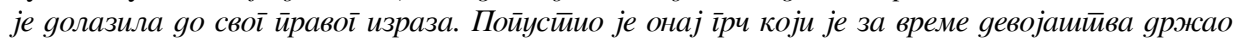

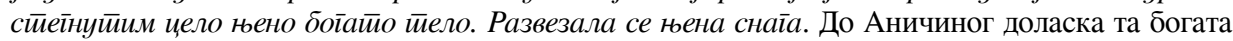
грађанска кућа ипак није заживела као топао породични простор и тек ће га она, нарочитом бригом и пажњом, саобразити својим потребама. 
се наочиглед света (одлазак у шетњу, позориште, биоскоп, на славу) - уступа место унутарњем, скривеном, нагонском.

Померање се очитује у још једној равни: активна постаје и темпорална опозиција: газда Андрија је некада живео у глувој тишини самачке собе у досади и самоћи, а сада је то замењено осећајем топлине, ширине, оплемењено присуством бића које ћути или повлађује. То даје повода за слободно говорење, гласно маштање и вербално ослобађање потиснутих садржаја. Унутрашњи простори дома попримају значење присности у односу на спољну средину, а присност је према својој најдубљој суштини - разоткривање (в. Фараго 2007: 93, 94). У коментаторским упадицама се упоредо са сваким Андријиним митоманским узлетом наглашава понеки физички недостатак овог лика, што оспорава његову размахнуту монолошку реч чинећи је смешном и неуверљивом. Кад пред женом говори о некадашњим љубавним искуствима, он је пејоративно означен као четкар или се читалачки фокус усмерава на његове чворновате прсте, на кошуљу најмање мушке нумере која постоји а пада му до земље, ћелаво теме с белом капицом или на тренутак када скида зубе са доње вилице, ставља вату у уво, заспива као животиња. Очигледно је приближавање перспективи из које се описује Андрија Зерековић, а то је Аничина тачка гледишта: „Када превласт узима субјективно виђење, када се аутор максимално поистовећује са својом јунакињом, поставља се иза ње и гледа помоћу ње” (Русе 1993: 175). Она га види као кукавца, али и као чуgовишие.$^{8}$ То двострано и двоструко приказивање дорађује и профилише аутор из своје свезнајуће визуре сажетим напоменама. Коначна процена је деградирајућа, лик четкара-митомана разобличен је и вулгаризован. У монолошким сеансама он себе ословљава пуним именом и презименом што указује на то да је његова свест о себи посредована мишљењем других, као и на сталну потребу за гратификацијом и доказивањем сопствене важности и непоколебљивог ауторитета. Андрија Зерековић све уме, све би могао, у свашта се разуме, без милосрђа би чинио шта је потребно, слао на робију и убијао ако треба. У завршници овог митоманског перформанса на зиду се од четкареве стиснуте песнице појављује растегнута сенка9 ${ }^{9}$ налик на неку пре-

\footnotetext{
${ }^{8}$ „[...] у ’Злостављању' [...] се газда Андрија појављује у два лица, у јавности као љубазан и достојанствен, а насамо са женом као монструм који се хвали како је спреман на најстрашније злочине” (Радоњић 2016: 734).

${ }^{9} \mathrm{O}$ сенкама као „присуству паралелног, невидљивог света” говори Н. Петковић поводом романа Сеобе. У тренутку када намамљује своју снаху, госпожу Дафину, у постељу, Аранђел подиже руку, а на зиду се појављује велика црна сенка. Сенка је ту симболизована предзнак је злокобне прељубе, а њено учестало јављање наговештава и мучне будуће догађаје (в. Петковић 1988: 274). У Андрићевој приповеци сенка одражава скривену, потмулу, тамну и опаку страну Андрије Зерековића. Симболизује, као што је и поређењем назначено, анимализацију његовог бића док се он, без мере и самоконтроле, речима и покретима разоткрива пред својом заплашеном и запрепашћеном женом.
} 
потопску животињу. Поново је потцртана анимална димензија његовог бића. Свет му изгледа ругобан и несавршен, а то би значило да сопствене физичке мањкавости пројектује и пресликава на све чиме је окружен.

Радња се успорава и отежава учесталошћу и варирањем сличних призора. Репортажа о убиству непознате жене има двоструку функцију у наративном склопу - газда Андрија кроз своју причу присваја идентитет убице за којим полиција трага. Изопачен рацио у наступу махните игре идентификације са злочинцем кратку жуту оловку присваја као смртоносно оружје: Нема

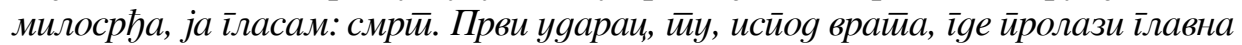
арйерија - на! - а зайим још йри уяариа, јеgан у леђа а gва у іруди - на! на! на! - и іот̄ово! Сви мисле да је Андрија Зерековић љубазан, добричина, а не знају и не слуте да је суштина скривена, маскирана и постоји латентна претьа да се управо пред женом разоткрије. Недостатак онтолошке утемељености и егзистенцијалне сигурности, исцрпљујуће трагање за идентитетом обликују лик гротескне и карикатуралне људске појаве, ужасавајући и йogсмешљив у исйи мах. Услед све интензивнијег топофобичног доживљаја, у Аничиној свести зачиње идеја о бекству или смрти као нечему што би донело ослобођење.

„Питања живота и смрти се интерпретирају у функцији присуства на одређеном месту, односно одсуства са њега. И мисао о преживљавању се јавља у оваквом просторном односу" (Фараго 2007: 68). У Аничином несрећном животу најпре је сан био вид побуне и спасавања од невоље, а потом су уследиле несанице и будно проживљавање могућег одметања и бега из огра-

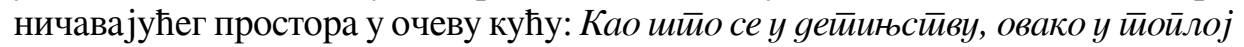

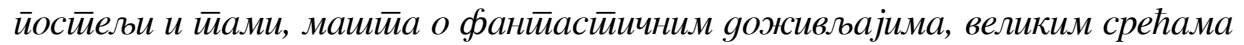
и чуяним усиессим, тиако она саgа замишља како би дивно и ситрашно било

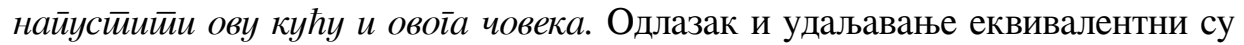
жељи за животом без свакодневних трауматичних искустава: Ocећа gобро колико би йо смело било, колико безумно и како сиирашно йо юу и неразумљиво

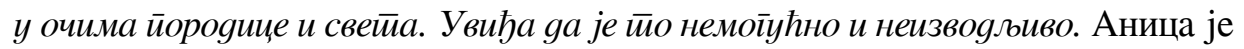
„заглибљена у својој тромости и предата лутању сопствених мисли; у затвореном простору где душа чами”, а „наставити живљење, после часова узлета [...] то увек значи пасти, поново падати у заточење" (у скученост - прим. наша) (Русе 1993: 170, 176). Свест о препрекама и мрежа забрана инхибирају било какву активност јунакиње, а живот се све више доживљава као страх од понављања драматичних ситуација којима је приморана да присуствује у улози немог сведока.

Проучавајући уметнички простор у Гогољевој прози, Ј. Лотман (1993: 274) запажа да су „кретања јунака такође преведена на језик позоришта они не чине безначајне покрете. Покрети се претварају у позе. Сценичност уметничког простора у призорима свакодневног живота манифестује се и у нечем другом - у изразитој наглашености граница уметничког простора.” 
Ова просторна омеђеност може се испољити и у томе што се радња одиграва у затвореној просторији (кућа, соба) уз приказивање њених граница (в. Лотман 1976: 300). У „Злостављању” је непробојност постигнута управо двоструким уобручавањем, јер је за вечерња збивања увек резервисана спаваћа соба, као потпростор. Прелазећи наизменично из једног у други простор, Андрија се деформише управо по законима датог простора (в. Лотман 1993: 294): пристојан и подобан дању, на послу и пред светом, претвара се у сопствену негацију кад дође вече. Остајући са женом насамо, показује своје, свету непознато наличје, и то само пред њом. Његово аутентично биће тада је за све друге скривено, само за Аницу видљиво. Два модела понашања на тај начин бивају условљена активирањем различитих типова простора. Језгро приповедне ситуације приближава се инсценацији. Глумац је у заносу, а у затвореном кућном простору има и једно посебно обезбеђено место за своју сценску uіру пуну покрета, гримаса, трансформација. Он је посебан тип умишљеника или хвалисавца који не примећује, или се прави да не примећује, своју социјалну инфериорност, трговац четкама који се пред женом представља стоструко већим него што јесте и себе види у главним историјским улогама (в. Пантић 2009: 176, 178). „Свугде има таквих људи”, каже и сам Иво Андрић коментаришући неке критичке приказе ове своје приповетке, „они би зачас уредили свет, средили националну економику, спречили ратове, епидемије, спутали цене" (Јандрић 1982: 126). Зерековићеви наступи све више су личили на митоманско оргијање. Прелазећи границе онога што је допуштено и природно, он постаје чудовиште, несвесно властитих поступака, егоманијак спреман да причом терорише и мучи. Аница је научила да се самосавлађује, да трпи и слуша. Премда је збуњена и зачуђена, жена све потврђује лаким покретима главе и ћутке, нейоколебљиво је мирна, йуна йонизной незнана и

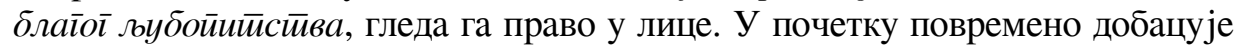
понеку реч, а с временом сасвим престаје да говори. Минус-присуство њеног вербалног испољавања последица је посебног вида изолације и недостатка комуникативности због живота у затвореном свету. Њихови брачни односи потпуно су нестали, док Аничина говорна обамрлост и бескрајно ћутање очаравају и заносе насилника. Свог мирног, пасивног гледаоца он збуњује и изненађује све непријатнијим и тежим монолозима, у чему додатно, безмало садистички, ужива. ${ }^{10}$

${ }^{10}$ Приповедање успоставља везе са другима, укида ћутање и самоћу бића. „Приметио сам одавно”, каже Иво Андрић (1998: 243), „,да људи који не умеју да причају нису способни ни да слушају туђе причање”. Има, међутим, и оних који се распричавају у жељи да по сваку цену надиђу реалне оквире сопствене личности па у митоманском узлету увек осуђују и деградирају друге, преувеличавају туђе мане, док самопохвала и величање личних идеја и домишљатости пред пасивним слушаоцем нарастају до неслућених димензија (в. Димитријевић 2012: 273). 
Спољашња радња је сиромашна, али се та монотонија неутралише лајтмотивским типом композиције, „у форми описа вишекратних збивања” (в. Лотман 1993: 285), значењски богатим понављањем неког мотива, речи, геста, ствари на одређеном месту: редовно, после вечере, Аница са плетивом седа испод лампе, у кут собе у заједничкој кући. Заузимање извесне позиције у односу на друге носи посебну комуникациону вредност и може се са психолошког, односно антрополошког аспекта тумачити као „проксемички знак”. ${ }^{11}$ Унутрашњи, затворен простор пружа сигурност, заштиту, и најчешће се изразито позитивно конотира као свој, пријатељски, артикулисан, познат и предвидљив. Таква поставка, међутим, захтева извесну корекцију приликом тумачења ове Андрићеве приповетке. Наиме, за јунакињу је овде карактеристичан обрнут доживљај простора: у кући осећа несигурност, умртвљеност, тескобу, топофобију, суочава се са злом и латентном опасношћу. Показује се како домаћи карактер куће може бити крајње привидан. За просторну структуру текста, опозиција отворен-затворен представља суштинско обележје и има најизразитију организациону улогу (в. Лотман 1976: 300). Могли бисмо је сматрати и једном од најважнијих и за семантизовање најрелевантнијих опозиција антрополошког простора. Наспрам отвореног, спољашњег, који је конотиран као туђ, непријатељски и хладан, затворен простор би требало да поседује супротна обележја: да се доживљава и ишчитава као топао и безбедан. Међутим, кућа у „Злостављању” не располаже семантичким потенцијалом којим је иначе одређена. Повезана је с ликом мужа митомана и његовим причањем пуним неодмерености, жестине, ироније, ћудљивости и нездраве маште. И док није непосредно присутан, жена с нелагодношћу све време очекује његов повратак. Зона приватног кућног поседа се зато више не опажа као „свој” простор, а упоредо с тим долази до промене Аничиног „телесног самоосећања" (в. Петковић 1988: 160) - појачава се агонални доживљај, њено тело постаје спутано и укочено од страха. Затворен простор, дакле, престаје да фигурира као традиционално повлашћен и умирујуће заклоњен, већ изазива кошмар, страх од специфичног типа „спацијалне инвазије” (Рот 2004: 213). Биће које представља претњу требало би да се налази у „туђем” ареалу $^{12}$, а овде је неодвојиви део заједничког животног амбијента, равно-

${ }^{11}$ „Језик просторних односа представља једно од основних средстава разумевања стварности” јер на основу бинарних опозиција, које у нашој свести организују простор, ми заправо стварамо модел организованости који поприма другачија, непросторна значења: антитетички упарени појмови високо-ниско, блиско-далеко, ойворено-зайворено преводе се у нову вредносно изнијансирану значењску раван и схватају се као релације вреgно-безвреgно, gобро-лоше, своје-тиуђе (в. Лотман 1976: 288).

${ }^{12}$ Ј. Лотман (1976: 300-301) указује на то да се простор у бајци, на пример, јасно рашчлањује на кућу и шуму. Граница између њих је разговетна - ивица шуме, каткад река па јунаци из шуме не могу да проникну у кућу - они су везани за одређен простор. Само се у шуми могу да дешавају страшни и чудотворни догађаји. Али, ако главни лик припада спољњем свету, опасност долази из затвореног, унутарњег, омеђеног света. Сама безбедност 
правно егзистира под истим кровом и отима духовну слободу ономе ко му је најближи. Андрија Зерековић се преображава у инвазора који је најпре заваљен у фотељи, а онда устаје, прилази ближе, седа на крај жениног кревета док се с њом не нађе лице у лице - чейкар ју је іонио gо у йосйељу; наgноси се чейкар инквизийорски нag њу - а она међу четири зида није налазила снаге да се брани, него је само стрепела, приклештена у кревету. Свакодневни простор претвара се у расцепкани не-простор; свакодневица прелази у хаос ${ }^{13}$ (расцепкану неорганизованост материје) што комуникацију чини немогућом и увећава неразумевање (в. Лотман 1993: 291, 293).

Пред крај се згуснутим понављањем поменутих детаља ритам приповедања убрзава, постављене опозиције се појачавају: дневна светлост и одсуство мужа из куће доносе мир и срећу, ноћ са којом се појављује његова прича подразумева муке и трпљење. У мислима јунакињи време тече брзо и неосетно, док је у непосредној стварности закочено: йрейурила би іо оине,

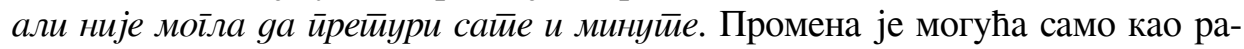
зарање унутарњег (кућног) простора (в. Лотман 1993: 285), у овом случају као растурање брачне везе која је и узроковала јунакињин боравак у таквом окружењу. Простор као место збивања подстиче јунака да промени постојећу егзистенцијалну форму - тако сазнајемо какве су му намере, жеље, потребе, какав је он заправо. Аница је депривилегована јунакиња и зато би требало да је и побуњена, али њу дуго не покреће пробуђена свест о сопственој тегобној скучености, о телесној патњи и „стезању простора” (в. Димитријевић 2011: 449): и gок мисли, млаgа жена осећа бол у ойежалим gојкама, бол који расиее

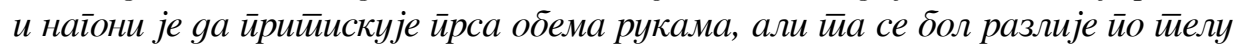
и она іучйа јаук са сузама; іушила се оg жеље gа бежи из ове зайушливе собе;

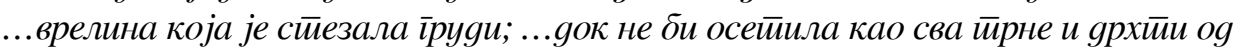
$\bar{u} в p g o \bar{\imath}$ хлаgной лежаја. Уколико мировање изједначимо са сваким потпуно детерминисаним кретањем, оно би наликовало ропству, непокретност би се као један тип закочености личности који се манифестује у невршењу радње (што би било значајније од простог померања у простору) - тумачила као немогућност јунака да измени свој статус (в. Лотман 1976: 294-295, 1993:

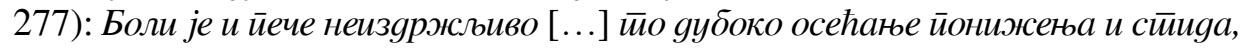

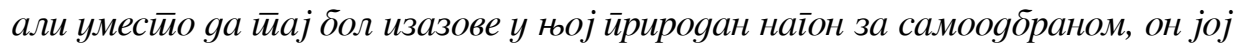
ояузима йоййуно реч, кочи йокрей, убија сваку одлуку у самој замисли. Таквој пасивности, неотпорности и неналажењу снаге супротстављена би била слобода која доноси бар могућност непредвидљивог, па би кретање отуда мо-

унутарњег света скрива претњу за лик овог типа. Зидови и ограде не изгледају као заштита, него се преобраћају у претеће елементе.

${ }_{13}^{13}$ „Неред и хаос у савременој се кибернетици и теорији информације назива ентропиja, а човекова се култура дефинише као победа над ентропијом, као смислена организација" (Петковић 2010: 48). 
гло да се схвати и као вид метаморфозе. Јунак може да се преобрази, односно да доживи повратак у некадашње стање, управо захваљујући дислокацији у простор који је квалитативно другачији, чиме би се уједно активирали сви његови позитивни духовни потенцијали.

Јунак који се креће има циљ - чак и кад је посреди ситан, себичан циљ и, у складу с тим, кратка трајекторија кретања - аутор га ипак издваја из света непокретних лутака (в. Лотман 1993: 308-309). Аница је мислила да тако огуглала може довека проводити живот у трпљењу крај свога распомамљеног мужа (в. Пантић 2009: 178). Јунакиња је предуго била статична, стегнута и закочена, „сведена на чисту пасивност, на неку врсту вегеталне свести која се под притиском насиља увлачи у себе док у једном тренутку не прсне у виду спонтаног и опет пасивног отпора" (Вучковић 1984: 389). Иво Андрић у вези са овим каже: „У ’Злостављању’ се жена нимало не одупире човеку који не зна за меру [...] за кога су жене могућност за духовно и свако друго злостављање" (Јандрић 1982: 127). Може нам се учинити како је њена одлука да се покрене нагла и немотивисана. Ипак, у причи је експлицитно саопштена, у свезнајућем ауторском маниру, мотивација трпљења, преображаја и одметања: $\overline{ш к в е ~}$

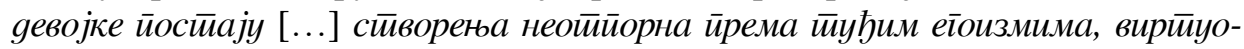

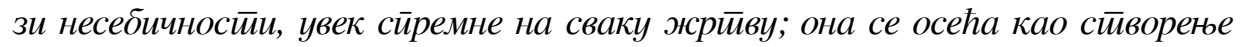
које злоуйойребљавају и злосииављају на безуушан, йоgмукао, а иривияно безазлен и gойушӣен начин. „Имам осећај” - вели Андрић - „да су критичари једнострани у оцени ове приповетке. Безмало сви истичу како сам ја ту бранио жену и заузимао се за њен положај. Није реч о томе. Жена је у овој приповеци нормална особа, а присиљена је да напусти свирепог мужа који је за свет око ње сасвим 'нормалан' и 'виђен' човек. Јер, тај свет каже: Осйавила онаквоі мужа" (Јандрић 1982: 125-126). Иво Андрић је зато у „Злостављању” пажљиво и хотимично припремио посебан стицај околности којима је усмерена Аничина изненадна покретљивост (пореметио се уобичајен редослед догађања у самој кући, муж се није вратио кад то иначе чини, девојка је некуд изашла) и тај нейрелазни и суgбоносни сай, моменат осамљења у кући, повод је за посебну узнемиреност и коначан прекид двоипогодишње тегобе. А онда, у снажном, још gевојачком йелу су оживели ошири, немирни итрнии, йанично усииремљени сви у јеgном ӣравцу, вуку је и іоне неодољиво из ове куће.

Финални обрт реализован је на следећи начин: јунакиња је на почетку била одређена као јеgна og мноїих а њен брак ни йо чему није ogygapao og остиалих, што је допринело нарастању очекивања да ће се и таква индивидуалност подредити социокултурним параметрима према којима је моделовано њено досадашње понашање ${ }^{14}$. Међутим, још једном се оно што је очеки-

${ }^{14}$ Уметнички лик се не изграђује само као реализација одређене културне схеме, него и као систем значајних одступања од ње. Та одступања на њеном фону смањују предвидљивост понашања главног јунака. Она образују извесно расејавање у јунаковом понашању око средње норме, коју прописује вануметничко схватање човекове природе. Оно што је у одређеном типу 
вано изневерава изглобљавањем из утврђеног тока: Али йо шито се gешава

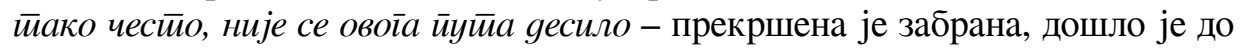
премештања преко границе. То је један од атипичних догађаја у приповеци, будући да се десило оно што се ретко догађа, односно што није требало да се догоди у том свету. Аница постаје јунак-дејствовалац ${ }^{15}$, прелази у семантичко антипоље - из равни имагинације и снова у зону акције - где се остварује замишљено и потпуно раскида веза са претходним животом. Тај немир је ну носио као сламку уз сиирму улицу и водио је йраво очинској кући. Кретање нагоре, према отвореном, широком, неомеђеном простору јесте кретање ка спасењу, симбол динамике унутрашњег преображаја. У наведеном се призору помаља снага као исход укрштаја стања људског бића са природним законитостима и силама. Немир је ослобађање активне енергије, прелазак из мировања у активност. Разматрањем висине у смислу обележја моралног линеарног простора, закључује се да зло долази одоздо, а спасење доноси полет навише, односно да је кретање јунака по његовој етичкој вертикали - успон или пад. Зато пут, као особен тип уметничког простора, односно путања кретање књижевног лика у том простору - поприма веома дубоко уметничко утемељење пошто се тиме метафорички представља морални препород (в. Лотман 1976: 292, 1993: 268-269, 304, 307). Аничин поступак, показало се, не можемо тумачити као хировит одлазак из мужевљеве куће без смисленог разлога. Реч је о очајничком чину спасавања сопственог живота и отимању преосталог унутрашњег мира, о узмицању пред навалом неконтролисаног деструктивног нагона и пред верб́алним изливањем мутних страсти једног самољубивог тиранина. Трпљење и немоћ пред хаосом су у једном моменту испровоцирали потребу да се „уреди, смислено организује свет око себе и у себи" (Петковић 2010: 47). ${ }^{16}$

Нека новија проучавања међузависности просторних елемената и карактеризације јунака у књижевном делу такође посматрају пут као „специфичан доживљај простора - то није место, него трагајуће кретање и назнака могућности преласка у једну пространију и слободнију сферу" (Фараго 2007: 75). Извесно је, и саопштено на почетку приче, да Аница у очевој кући није

културе једино могућа норма понашања, у уметничком тексту се остварује као одређени скуп могућности који се у његовим границама само делимично реализује (в. Лотман 1976: 325).

${ }^{15}$ Ј. Лотман (1976: 311) уводи посебан појам: личност која прелази границе семантичкога или сижејнога поља у које је смештена. То је личност у акцији, дејствовалац чијим се деловањем сиже развија.

${ }^{16}$ Додајемо овоме још једно запажање Н. Петковића (2010: 47) о смисаоној суштини Андрићевог опуса: „У целини гледано, Андрић је у свим својим делима, и из различитих углова, приказивао борбу човека са бесмислом, ентропијом јер Иво Андрић је - могли бисмо рећи - писац културе, тј. писац који је више но било ко други у нашој књижевности заокупљен човековим настојањем да по мери свога ума доведе у ред свет у коме живи.” 
успела да нађе стабилност јер ту није више била добродошла. Онемогућено је успостављање ранијег поретка и враћање у првобитну ситуацију. Телесно згрчена и спутана у примарном породичном простору, потом привремено ослобођена у мужевљевој кући где се, у почетку, њено стасито, једро, здраво и младо тело кретало слободно и мирно, све док није доведена у стање потпуне просторно-егзистенцијалне стешњености, Аница ће, после развода, своје усамљеничке дане проводити у једној собици на петом спрату. Верујемо да се Андрић није случајно послужио деминутивом, него да је то квалификација, димензионирање простора у којем, после свега, његова јунакиња борави. Разумевање реалистички конципиране слике зауставило би се на рационалној претпоставци да је Аница себи могла да приушти једино такав скроман дом ( јер су на вишим спратовима станови јефтинији). Пођемо ли трагом извесне симболизације и од уверења да „иза свих прича које у његовој [Андрићевој] прози налазимо, можемо дослутити и древни мит о борби између светлости и таме, добра и зла" (Петковић 2010: 47), отвара нам се још једна могућност за семантизовање просторних детаља у приповеци „Злостављање”. Аничина собица јесте невелика, према томе и скучена, али је лоцирана тако да на помињаној вертикали горе-доле заузима уздигнуто место и представља зону ван домашаја злостављача. Симболизам броја пет упућује на средиште, склад и равнотежу, ред и савршенство, спајање небеског и земаљског принципа (в. Гербран, Шевалије 2004: 695-696). Ма како суморно и усамљенички изгледао јунакињин живот, она је, иако пасивним отпором, ипак надишла зло и таму који су у једном моменту запосели и чврсто уобручили њено биће. У простору који више нико неће узурпирати, недељом може да се йройере $u$ окрйи, заклоњена и помирена са собом и својом судбином.

\section{ИЗВОРИ}

Андрић (1967): И. Андрић, Знакови - приповетке, Сабрана дела - књига осма, Београд, 105-133.

Андрић (1994): И. Андрић, Писаи іовори својим gелом, Београд: Београдски издавачко-графички завод - Српска књижевна задруга.

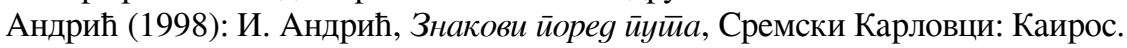

\section{ЛИТЕРАТУРА}

Бужињска, Марковски (2009): A. Bužinjska, M. P. Markovski, Književne teorije $X X$ veka, Beograd: Službeni glasnik.

Вучковић (1974): R. Vučković, Velika sinteza, Sarajevo: „Svjetlost”.

Димитријевић (2011): М. Димитријевић, Карактеризација јунака елементима простора у књижевним текстовима за децу, Савремена ирроучавања језика и книжевносиии, књига 2, Крагујевац: ФИЛУМ, 447-454. 
Димитријевић (2012): М. Димитријевић, Једна те иста бескрајна прича, Свеске Заяужбине Иве Анярића, 29/12, Београд: Задужбина Иве Андрића, 260-281.

Јандрић (1982): Lj. Jandrić, Sa Ivom Andrićem, Sarajevo: IRO „Veselin Masleša”.

Леовац (1979): С. Леовац, Прийовеgач Иво Анgрић, Нови Сад: Матица српска. Лотман (976): J. Lotman, Struktura umetničkog teksta, Beograd: Nolit.

Лотман (1993): J. Lotman, Umetnički prostor u Gogoljevoj prozi, Beograd: Treći program, 96/99, 263-310.

Микић (2005): Р. Микић, Прича, сан и манифест. Један поглед на Дневник о Чарнојевићу, у Кюиїа о Црњанском, Београд: Српска књижевна задруга, 98-129.

Пантић (1999): M. Pantić, Modernističko pripovedanje, Beograd: Zavod za udžbenike i nastavna sredstva.

Пантић (2009): М. Пантић, Неизиуубљено време, Београд: Службени гласник.

Петковић (1988): Н. Петковић, Два срйска романа, Београд: Народна књига. нике.

Петковић (2010): Н. Петковић, На извору живе воgе, Београд: Завод за уџбе-

Радоњић (2016): Г. Радоњић, Андрић и традиција свјетске приповјетке: тема подвојеност лика, Зборник Майице срӣске за книжевносӣ и језик, LXIV/3, Нови Сад, 731-741.

РСJ (2007): Речник срйскоїа језика, Нови Сад: Матица српска.

Рот (2004): N. Rot, Znakovi i značenja: verbalna i neverbalna komunikacija, Beograd: Plato.

Русе (1993): Ж. Русе, Облик и значење, Сремски Карловци, Нови Сад: Издавачка књиж. 3. Стојановића.

Фараго (2007): K. Farago, Dinamika prostora, kretanje mesta: studije iz geokulturalne naratologije, Novi Sad: Stylos.

Флоренски (2013): P. Florenski, Prostor i vreme u umetničkim delima, Beograd: Službeni glasnik.

Гербран, Шевалије, (2004): A. Gerbran, Ž. Ševalije, Rečnik simbola: mitovi, snovi, običaji, postupci, oblici, likovi, boje, brojevi, Novi Sad: Stylos - Kiša.

\section{Maja M. Dimitrijević}

University of Kragujevac

Faculty of Education in Jagodina

Department of Didactics and Methodology

\section{SPATIAL RELATIONS LANGUAGE IN ANDRIĆ'S STORY "ZLOSTAVLJANJE"}

Summary: The paper explores the way elements related to space influence readers' reception of characters and events in Andrić's story "Zlostavljanje" (1946). On the basis of "spatial relations language", the ethno-psychological dimension of family relations and the issue of the destruction of the institution of marriage in the specific socio-cultural context 
is analyzed. The research focused on the complex description of the characters, where spatial opposites on the vertical axis (up-down) play an important role, and particularly the opposites on the horizontal plane (inside-outside). In the artistic world of Andrić's story, the house becomes a metaphor for reconcilied extremes - desired and achieved, forbiden and permitted. On the other hand, the space of the house has a topophobic conotation as well, since it generates the idea of escape or death, which is, for the main character, equal to deliverance and final salvation. It has been concluded that the structure of space represents one of the essential expressive means which directly influence characterization and transformation/deformation of the characters in the story "Zlostavljanje".

Keywords: Ivo Andrić, "Zlostavljanje”, literary character, space, spatial relations, topophobia. 